\title{
Balanced Scorecard como suporte às decisões gerenciais: estudo comparativo entre propriedades produtoras de leite
}

\author{
[Balanced Scorecard as support to management decisions: comparative study between milk \\ producers properties]
}

\section{"Artigo Científico/Scientific Article"}

\author{
Antônio Augusto Brion Cardoso ${ }^{1}$, Marcos Aurelio Lopes ${ }^{2 *}$, Francisval Carvalho de Melo ${ }^{3}$, \\ Rodrigo Andrade Ferrazza ${ }^{4}$, André Luís Ribeiro Lima ${ }^{3}$, Milton Ghedini Cardoso ${ }^{2}$
}

\author{
${ }^{1}$ Universidade Federal de Juiz de Fora, Juiz de Fora-MG, Brasil. \\ ${ }^{2}$ Departamento de Medicina Veterinária, Universidade Federal de Lavras, Lavras-MG, Brasil. \\ ${ }^{3}$ Departamento de Administração e Economia, Universidade Federal de Lavras, Lavras-MG, Brasil. \\ ${ }^{4}$ Universidade Federal de Goiás, Goiânia-GO, Brasil. \\ *Autor para correspondência/Corresponding author: E-mail: malopes@dmv.ufla.br
}

\begin{abstract}
Resumo
Objetivou-se analisar a aplicabilidade da ferramenta de gestão Balanced Scorecard (BSC) em propriedades produtoras de leite, localizadas no sul de Minas Gerais (MG). Pretendeu-se, ainda, realizar um comparativo da sua aplicabilidade em propriedades com diferentes escalas de produção e níveis tecnológicos. O levantamento das informações foi realizado por meio de entrevistas semiestruturadas realizadas in loco. Como instrumentos de coleta de dados foram utilizados a entrevista pessoal, a análise documental e a observação direta e participante. Para a adaptação do BSC foi realizado o levantamento das características das três propriedades, com a identificação dos seus pontos fortes e fracos, bem como das variáveis chaves de sucesso, base para a formulação da missão e visão estratégica de cada uma. Ao final foi proposto um painel de indicadores de desempenho para auxiliar as decisões gerenciais, bem como elaborado o mapa estratégico para cada uma. Desta forma, compreende-se que a ferramenta gerencial Balanced Scorecard pode ser adaptada a propriedades rurais produtoras de leite, independente do seu nível tecnológico e escala de produção. No entanto, para que se alcance o sucesso na implantação da ferramenta, a estratégia organizacional deve ser conhecida por todos os envolvidos e, claro, exige-se o acompanhamento sistemático por parte dos gestores.
\end{abstract}

Palavras-chave: escala de produção; nível tecnológico; pecuária leiteira; planejamento estratégico.

\begin{abstract}
The objective was to analyze the applicability of the Balanced Scorecard (BSC) management tool in dairy farms located in the south of Minas Gerais. Also, a comparative study of its applicability in properties with different scales of production and technological levels was also performed. Semi-structured interviews carried out in loco were the foundation of the survey. Data collection tools used were personal interviews, document analysis, and direct and participant observation. A survey was necessary to adapt the BSC according to characteristics of the three properties, identifying their strengths and weaknesses, as well as the key success variables, the basis for the formulation of the mission and strategic vision of each. In the end, an indicator performance panel was proposed to assist management decisions, and a strategic map drawn for each property. To the authors knowledge, Balanced Scorecard management tool can be adapted to dairy farms, regardless of their technological level and production scale. However, in order to achieve success in implementation of the tool, the organizational strategy must be familiar to all involved and, of course, systematic monitoring by managers is required.
\end{abstract}

Keywords: dairy farming; production scale; strategic planning; technological level. 


\section{Introdução}

Grandes transformações têm influenciado o setor da pecuária leiteira no Brasil nos últimos anos. Elas possuem relação direta com os impactos advindos da estabilização monetária, da desregulamentação do mercado com o fim do controle estatal sobre os preços, em grande parte dos setores, da abertura econômica e da mudança nos padrões de consumo da população. Como se não bastasse as mudanças econômicas, outras questões têm colocado em check o setor primário brasileiro. A necessidade urgente de modernização do sistema produtivo, a crescente pressão política para uso intensivo das propriedades com vistas ao cumprimento da função social da terra, modificações da legislação ambiental, bem-estar animal; além disso tudo, tem-se a tradição e a cultura que, atualmente, são dimensões que devem ser levadas em consideração na gestão de propriedades rurais.

Mesmo com todas essas questões, verificase que a atividade pecuária leiteira no Brasil, vem crescendo e tem potencial de crescimento ainda maior, porém, é necessária uma modernização da gestão com a incorporação de novas ferramentas de gestão como forma de auxiliar a melhoria dos resultados. Oaigen et al. (2008) afirmaram que a maior adoção das funções administrativas de planejamento, organização, direção e controle, por parte dos produtores rurais, podem contribuir positivamente para melhorar o resultado econômico de suas empresas. Todavia, apesar dessa provável associação positiva entre o uso de técnicas de gerenciamento e o sucesso econômico das empresas rurais, tem-se observado que a esmagadora maioria das fazendas brasileiras ainda não adota, de maneira formal e eficiente, várias técnicas já consagradas de administração, que poderiam proporcionar maior competitividade aos negócios (Godinho et al., 2013).

Como forma de minimizar essa visão míope de gestão, o Balanced Scorecard (BSC) foi criado como uma ferramenta de gestão que busca incorporar aos indicadores financeiros já usados, os indicadores não-financeiros e, assim, melhorar a avaliação de desempenho das organizações. $\mathrm{O}$ BSC é definido como uma metodologia capaz de estimular a organização a criar visão de futuro; favorece também o estabelecimento de estratégias de longo prazo, por meio de indicadores e medidas de desempenho e, como consequência, possibilitarão a gestão estratégica. O BSC auxilia a equilibrar os objetivos e perspectivas de negócios, por meio da ponderação entre objetivos financeiros e não-financeiros (Kaplan e Norton, 1997). Ele tem por finalidade ajudar o executivo a "pilotar" a empresa mediante a identificação de fatores-chave de sucesso, principalmente aqueles que podem ser medidos por variáveis físicas (Padoveze, 2009).

$\mathrm{Na}$ literatura internacional são descritas algumas abordagens para a gestão e utilização do BSC em empresas do agronegócio, cadeia de produção da carne e abastecimento alimentar (Shadbolt, 2007; Jack, 2009; Bigliardi e Bottani, 2010; Bryceson e Slaugther, 2010). Considerando a relevância do tema, bem como a inexistência de artigos científicos sobre a aplicação do BSC na atividade leiteira do Brasil, apresenta-se este estudo diante da seguinte problemática: Como adaptar os princípios do Balanced Scorecard a uma propriedade produtora de leite, independente do seu tamanho e nível tecnológico, com intuito de aumentar a eficiência do seu sistema de gestão?

Com base nisso, objetivou-se analisar a aplicabilidade do Balanced Scorecard (BSC) em propriedades produtoras de leite, localizadas no sul de Minas Gerais. Pretendeu-se, ainda, realizar um comparativo da sua aplicabilidade em propriedades com diferentes escalas de produção e níveis tecnológicos. Especificamente, pretendeuse desenvolver um modelo de indicadores de desempenho com base no BSC e propor um painel de indicadores estratégicos para cada uma delas, visando estimular o processo de medição de desempenho, fornecendo, assim, suporte às decisões gerenciais e apoiando a melhoria contínua na atividade pecuária leiteira.

\section{Material e Métodos}

A pesquisa caracteriza-se como exploratória quanto aos objetivos (Salomon, 1999) e, de caráter qualitativo (Spector, 2002), quanto à natureza. Especificamente um estudo de caso (Triviños, 1987; Yin, 2005).

A escolha da região sul do estado de Minas Gerais é justificada pela sua tradição e importância enquanto bacia leiteira do estado. Já as unidades de análise foram escolhidas levandose em consideração os seguintes critérios: disponibilidade dos proprietários para participar da pesquisa, bem como interesse na realização da mesma e facilidade de acesso por parte dos pesquisadores às fontes de evidências.

A partir do conhecimento da teoria relacionada ao BSC, se determinou uma sequência 
lógica de estruturação e proposição da ferramenta às empresas objetos deste estudo. A pesquisa qualitativa foi desenvolvida visando a proposição de painéis de indicadores de medição de desempenho, baseado na metodologia do BSC.

A execução do trabalho teve como base a interação entre os pesquisadores e os gestores para quem foram feitas a apresentação do projeto na íntegra, com o objetivo de informá-los de toda a metodologia. Houve também um encontro entre os pesquisadores e os colaboradores com intuito de motivar o grupo para a aplicação do método.

Como instrumentos de coleta de evidências foram utilizados a entrevista semiestruturada (Triviños, 1987), por meio de um formulário semiestruturado que mescla questões de caráter qualitativo e quantitativo, que foi desenvolvido com o objetivo de coletar informações para a elaboração de um levantamento minucioso de dados e informações direcionadas à composição de uma visão geral e avaliação dos fatores críticos de sucesso das empresas. Esse formulário foi dividido em quatro partes; e todas as questões respondidas pelos proprietários. A primeira parte é referente à caracterização da propriedade, tamanho, estrutura física, atividades, quantidade de funcionários etc. A segunda, refere-se ao rebanho e a produção do leite, qual o tamanho, a raça, o tipo e a quantidade de leite produzida etc. A terceira parte diz respeito a gestão da propriedade, a gestão financeira, gestão de pessoas e gestão comercial. A quarta, e última, leva em consideração a parte estratégica da propriedade. Devido a extensão do questionário, sua aplicação foi dividida em vários dias e as respostas foram gravadas e posteriormente transcritas na íntegra, o que possibilitou uma análise de conteúdo mais apurada.

Fizeram parte também da pesquisa, a análise documental e da observação direta e participante que, para Yin (2005), o observador não é um agente passivo, ele participa ativamente do processo que está sendo investigado. O exame de documentos permitiu complementar as demais técnicas e verificar a validade dos dados, além de permitir acesso a outras informações. A observação direta e participativa permitiu ainda aprimorar o conhecimento do comportamento e da comunicação das pessoas por meio da imersão no ambiente estudado. A pesquisa foi realizada nos meses de janeiro a dezembro de 2013.

Para a proposição do conjunto de indicadores de desempenho da empresa, foram realizadas as seguintes etapas: a) identificação da missão, objetivo e visão das empresas; b) análise das alternativas estratégicas; c) determinação das perspectivas de valor do BSC; d) construção do mapa estratégico; e e) determinação dos indicadores de medição de desempenho agrupados dentro da visão do BSC, entre financeiros, de clientes, de processos e de aprendizado (Kaplan e Norton, 1997), assegurando-se de que todas as perspectivas tenham sido contempladas.

A soma desses procedimentos permitiu o tratamento e análise dos dados, constituindo-se como uma ferramenta para o desenvolvimento e avanço da gestão estratégica da atividade econômica em estudo. A análise dos dados foi feita tomando como base todo material coletado em campo, bem como as observações realizadas in loco. Os dados foram analisados e interpretados por meio da análise de conteúdo que, segundo Gil (2002), é uma metodologia que busca a compreensão da construção de significados que o pesquisado exterioriza no seu discurso.

\section{Resultados e Discussão}

As propriedades visitadas são identificadas como propriedades 1,2 e 3 , no intuito de preservar a identidade das mesmas. Para uma melhor compreensão dos resultados da pesquisa, foi proposto um quadro comparativo, dividido em três tabelas. Na Tabela 1, estão apresentadas as características gerenciais, relativas à propriedade, ao rebanho, a administração e a gestão financeira das três propriedades.

As três propriedades são bem distintas, principalmente no que tange à área total, atividades exploradas, tamanho do rebanho, processo de ordenha e produção. De acordo com a Tabela 1, todas as propriedades possuem atividades em comum, só difere a propriedade 1 a possuir suinocultura a mais. Porém, quando se compara a gestão, percebe-se uma semelhança entre elas, pois é comum em todas a falta do planejamento e controle financeiro. De acordo com Lopes (2015), o sucesso de uma propriedade leiteira é consequência de um bom planejamento, em seus diversos aspectos e componentes do sistema de produção. Outro ponto comum entre as propriedades é a falta de controle de entrada e saída de recursos. A gestão dos recursos dentro de uma organização é muito importante, e o seu controle deve ser realizado por meio de uma ferramenta chamada fluxo de caixa. Assaf Neto (2014) afirmou que o fluxo de caixa, além de ser 
uma ferramenta de controle de entrada e saída de recursos, é também uma ferramenta de fácil compreensão dos dados, o que facilita a tomada de decisão por parte do gestor.

Um ponto a se destacar nesta Tabela comparativa é a produtividade média de litros de leite por animal. Na propriedade 1, onde há uma estrutura mais adequada às necessidades dos animais, lhes proporcionando mais conforto, o Free stall e sala de ordenha, a média é de 26,6 litros, enquanto que, na 3, onde não há nenhuma dessas estruturas e, ainda, o gado ficou solto no pasto, a média foi bem menor, de 15,9 litros. Paixão et al. (2014) destacaram que uma infraestrutura adequada é fundamental, pois auxiliam na manutenção da higiene e no conforto do animal, o que acaba por influenciar na qualidade final do produto e também na sua quantidade.

Tabela 1. Comparativo gerencial de três propriedades com diferentes escalas de produção e níveis tecnológicos localizadas no sul do estado de Minas Gerais.

\begin{tabular}{|c|c|c|c|}
\hline & Propriedade 1 - Grande & Propriedade 2 - Média & Propriedade 3 - Pequena \\
\hline 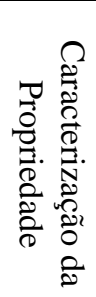 & $\begin{array}{l}\text { - Total da área usada: } 504 \text { ha: } \\
100 \% \text { é de sua propriedade } \\
\text { - Possui } 8 \text { funcionários } \\
\text { permanentes + } 0 \text { temporários } \\
\text { - Atividades: Leiteira ( } 70 \% \text { do } \\
\text { faturamento), suinocultura ( } 10 \%) \\
\text { e café }(20 \%)\end{array}$ & $\begin{array}{l}\text { - Total da área usada: } 396 \text { ha: } \\
40 \% \text { arrendada } \\
\text { - Possui } 6 \text { funcionários } \\
\text { permanentes + } 2 \text { temporários } \\
\text { - Atividades: Leiteira }(60 \% \text { do } \\
\text { faturamento) e café }(40 \%)\end{array}$ & $\begin{array}{l}\text { - Total da área usada } 216 \text { ha: } \\
80 \% \text { arrendada } \\
\text { - Proprietário é o único } \\
\text { trabalhador } \\
\text { Atividades: Leiteira }(80 \% \text { do } \\
\text { faturamento) e café }(20 \%)\end{array}$ \\
\hline 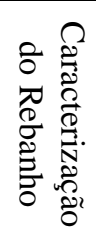 & $\begin{array}{l}\text { - Vacas em lactação: } 225 \\
\text { - Raça: holandês PO/PC } \\
\text { - Gado confinado. Free-Satll } \\
\text { - } 6.000 \text { litros/dia - média 26,6 } \\
\text { litros }\end{array}$ & $\begin{array}{l}\text { - Vacas em lactação: } 164 \\
\text { - Raça: holandês PO/PC } \\
\text { - Gado semi-confinado. } \\
\text { - 3.200litros/dia - média 19,51 } \\
\text { litros }\end{array}$ & $\begin{array}{l}\text { - Vacas em lactação: } 22 \\
\text { - Raça: } 3 / 4 \text { holandês } \\
\text { - Gado no pasto } \\
\text { - } 350 \text { litros/dia - média 15,9 } \\
\text { litros }\end{array}$ \\
\hline 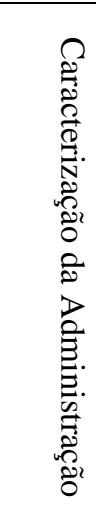 & $\begin{array}{l}\text { - Não há um planejamento } \\
\text { formal, o único planejamento é } \\
\text { para manutenção das máquinas e } \\
\text { equipamentos } \\
\text { - Máquinas e equipamentos } \\
\text { precisam de mais investimentos } \\
\text { - Distribuição de funções é } \\
\text { clara. As atividades são } \\
\text { distribuídas de acordo com a } \\
\text { capacitação do funcionário. }\end{array}$ & $\begin{array}{l}\text { - Não há um planejamento } \\
\text { formal, o único planejamento é } \\
\text { para manutenção das máquinas e } \\
\text { equipamentos } \\
\text { - Máquinas e equipamentos } \\
\text { precisam de mais investimentos. } \\
\text { - Distribuição de funções é } \\
\text { clara. As atividades são } \\
\text { distribuídas de acordo com a } \\
\text { capacitação do funcionário. }\end{array}$ & $\begin{array}{l}\text { - Não há qualquer tipo de } \\
\text { planejamento, nem para } \\
\text { manutenção das máquinas e } \\
\text { equipamentos. Manutenção } \\
\text { corretiva. } \\
\text { - Infraestrutura precisa de } \\
\text { melhorias, porém, as máquinas e } \\
\text { equipamentos são adequados } \\
\text { para as atividades. } \\
\text { - Por ser constituída de apenas } \\
\text { um funcionário, não há divisão } \\
\text { do trabalho }\end{array}$ \\
\hline 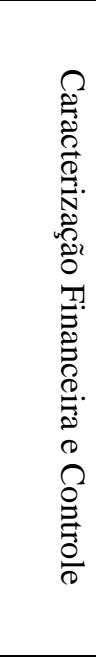 & $\begin{array}{l}\text { - Não há controle de entradas e } \\
\text { saídas de dinheiro (fluxo de } \\
\text { caixa) por desinteresse, mas sabe } \\
\text { que os resultados são } \\
\text { satisfatórios. } \\
\text { - Os funcionários não conhecem } \\
\text { os objetivos da empresa. Não } \\
\text { realiza reuniões periódicas. } \\
\text { - Funcionário não é estimulado } \\
\text { a melhorar. } \\
\text { - Salário acima da média. } \\
\text { - Controle de estoque não é } \\
\text { confiável. } \\
\text { - Faz comparações entre } \\
\text { propriedades para realizar } \\
\text { melhorias }\end{array}$ & $\begin{array}{l}\text { - Não há controle de entradas e } \\
\text { saídas de dinheiro (fluxo de } \\
\text { caixa) por desinteresse, mas sabe } \\
\text { que resultados são satisfatórios. } \\
\text { - Os funcionários não conhecem } \\
\text { os objetivos da empresa. Não } \\
\text { realiza reuniões periódicas. } \\
\text { - Funcionário não é estimulado } \\
\text { a melhorar } \\
\text { - Salário acima da média. } \\
\text { - Faz comparações entre } \\
\text { propriedades para realizar } \\
\text { melhorias }\end{array}$ & $\begin{array}{l}\text { - Não há controle de entradas e } \\
\text { saídas de dinheiro (fluxo de } \\
\text { caixa), mas sabe que os } \\
\text { resultados não são satisfatórios. } \\
\text { - Realiza a contratação de } \\
\text { funcionários temporários e com } \\
\text { base na necessidade. Não pensa } \\
\text { em contratação definitiva. } \\
\text { - Salário da contratação } \\
\text { temporária é na média paga pelo } \\
\text { mercado. } \\
\text { - Utiliza da venda de animais } \\
\text { para cobrir o caixa } \\
\text { - Faz apenas o mínimo } \\
\text { necessário para atingir o padrão }\end{array}$ \\
\hline
\end{tabular}

Fonte: Dados da pesquisa 
Sobre os recursos humanos disponíveis, a propriedade 3 foi a única que não possuiu funcionários devido a sua pequena escala de produção. Porém, nas demais, os funcionários foram divididos nas tarefas de acordo com sua capacitação e realizaram atividades de forma rotineira e sem o conhecimento da finalidade de suas ações. Muito disso pode ser atribuído à falta de reuniões entre gestor e colaboradores.
Depois da caracterização das fazendas, as entrevistas buscaram identificar os pontos fundamentais para a elaboração de um plano estratégico para cada uma delas. Na Tabela 2 foram apresentados os pontos fortes e fracos, missão, visão, diretrizes estratégicas e pontos críticos de sucesso.

Tabela 2. Comparativo estratégico de três propriedades com diferentes escalas de produção e níveis tecnológicos localizadas no sul do estado de Minas Gerais.

\begin{tabular}{|c|c|c|c|}
\hline & Propriedade 1 - Grande & Propriedade 2 - Média & Propriedade 3 - Pequena \\
\hline 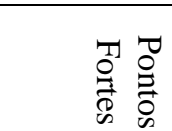 & $\begin{array}{ll}\text { Infraestrutura (instalações) } & \text { e } \\
\text { recursos humanos (lealdade) } & \end{array}$ & $\begin{array}{l}\text { Localização, infraestrutura e } \\
\text { fonte de água potável. }\end{array}$ & $\begin{array}{l}\text { Baixo custo com mão de obra e } \\
\text { conhecimento de todas as } \\
\text { atividades (processos) }\end{array}$ \\
\hline 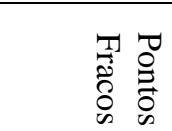 & Planejamento e Controle & $\begin{array}{l}\text { Mão-de-obra (especialização), } \\
\text { Planejamento e Controle }\end{array}$ & $\begin{array}{l}\text { Instalações, Planejamento e } \\
\text { Controle }\end{array}$ \\
\hline 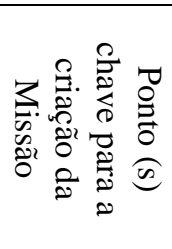 & $\begin{array}{l}\text { Melhorar qualidade dos } \\
\text { produtos produzidos, busca pela } \\
\text { inovação e aproveitamento dos } \\
\text { subprodutos. }\end{array}$ & $\begin{array}{l}\text { Implantação de melhorias no que } \\
\text { diz respeito à gestão, busca de } \\
\text { qualidade dos produtos e } \\
\text { melhoria dos recursos humanos. }\end{array}$ & $\begin{array}{l}\text { Melhorar o conforto do gado, } \\
\text { reduzindo assim o stress do } \\
\text { manejo com intuito de aumentar } \\
\text { a produção e a qualidade do leite } \\
\text { com a mesma quantidade de } \\
\text { animais. }\end{array}$ \\
\hline 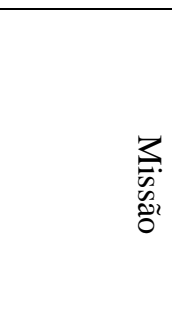 & $\begin{array}{l}\text { "Ter a inovação como parceira } \\
\text { com intuito de proporcionar } \\
\text { uma melhor qualidade dos } \\
\text { produtos e, consequentemente, } \\
\text { melhor resultado, sem se } \\
\text { descuidar do meio-ambiente e } \\
\text { da sustentabilidade do negócio." }\end{array}$ & $\begin{array}{l}\text { "Procurar estar sempre em } \\
\text { sintonia com as melhores práticas } \\
\text { aplicáveis a gestão da } \\
\text { propriedade, aos recursos } \\
\text { humanos e sistema de produção, } \\
\text { afim de proporcionar uma } \\
\text { qualidade superior no que } \\
\text { produz." }\end{array}$ & $\begin{array}{l}\text { "Alcançar o máximo da } \\
\text { eficiência produtiva e da } \\
\text { qualidade final de seus produtos, } \\
\text { a partir da implementação de } \\
\text { ações que proporcionem aos } \\
\text { animais melhores condições } \\
\text { desde o manejo até a ordenha." }\end{array}$ \\
\hline $\begin{array}{l}\leq \\
\text { : } \\
\hat{\sigma}^{2}\end{array}$ & $\begin{array}{l}\text { Ser reconhecida na região } \\
\text { pela qualidade dos seus } \\
\text { produtos e referência no que } \\
\text { tange a aproveitamentos de } \\
\text { seus subprodutos }\end{array}$ & $\begin{array}{l}\text { Ser reconhecida na região pela } \\
\text { gestão eficaz e pela qualidade } \\
\text { dos seus produtos. }\end{array}$ & $\begin{array}{l}\text { Ser reconhecida como uma } \\
\text { propriedade eficiente na } \\
\text { produção de leite e que fornece } \\
\text { aos seus clientes produtos de } \\
\text { qualidade. }\end{array}$ \\
\hline 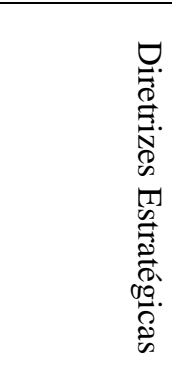 & $\begin{array}{l}\text { - } \text { Criar valor para } \\
\text { proprietários por meio do } \\
\text { aumento do lucro; } \\
\text { - Melhoria na gestão; } \\
\text { - Fornecer produtos } \\
\text { qualidade superior aos seus } \\
\text { clientes; } \\
\text { - Preservação do meio- } \\
\text { ambiente. }\end{array}$ & $\begin{array}{l}\text { - Capacitação dos recursos } \\
\text { humanos, } \\
\text { - Melhorias na infraestrutura de } \\
\text { confinamento do gado } \\
\text { - Melhor aproveitamento da área } \\
\text { disponível. }\end{array}$ & $\begin{array}{l}\text { - Aumento da lucratividade; } \\
\text { - Fornecer produtos de } \\
\text { qualidade; } \\
\text { - Conforto e bem-estar dos } \\
\text { animais }\end{array}$ \\
\hline 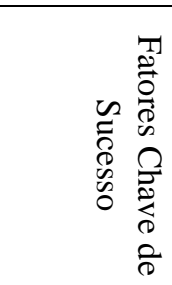 & $\begin{array}{l}\text { 1. Melhorar a gestão de compras } \\
\text { e apuração de custos por meio } \\
\text { de treinamentos e softwares; } \\
\text { 2. Aumentar a qualidade do leite } \\
\text { vendido; } \\
\text { 3. Investir em ações } \\
\text { sustentáveis. }\end{array}$ & $\begin{array}{l}\text { 1. Investir mais recursos na } \\
\text { capacitação dos recursos } \\
\text { humanos disponíveis; } \\
\text { 2. Investir em tecnologias que } \\
\text { tornem a gestão mais eficaz; } \\
\text { 3. Aumentar a qualidade do leite } \\
\text { produzido. }\end{array}$ & $\begin{array}{l}\text { 1. Melhorar a infraestrutura; } \\
\text { 2. Aumentar a qualidade do leite } \\
\text { vendido; } \\
\text { 3. Investir em treinamentos } \\
\text { voltados à gestão. }\end{array}$ \\
\hline
\end{tabular}


Pela análise dos pontos fortes, ficou nítido a diferença entre as propriedades, apesar de cada uma apresentar suas vantagens nesse quesito. Isto porque, quando se trata de infraestrutura de produção, segundo Lopes (2015), a otimização da infraestrutura, pelo aumento da escala de produção, até determinados níveis, resultará na redução do custo médio com depreciação, com consequente aumento na lucratividade. No caso da propriedade 2, o fato de se ter água potável na propriedade, trouxe os benefícios com baixa contaminação por coliformes e outros gêneros bacterianos como Pseudomonas e Bacillus (Cousin e Bramley, 1990). O leite pode ser contaminado quando em contato com a superfície do equipamento e/ou utensílios de ordenha, assim como no próprio tanque de refrigeração. A contagem bacteriana total do leite pode aumentar significativamente quando em contato com equipamentos nos quais a limpeza e sanitização são deficientes, pois os microrganismos proliferam nos resíduos de leite presentes em recipientes, borrachas, junções e qualquer outro local onde ocorra acúmulo de resíduos de leite. Já em relação à propriedade 3 , trabalhar sozinho traz suas vantagens, pois assim o pecuarista tem o conhecimento de todos os processos, do início ao fim, além de ter um reduzido custo de mão de obra que, segundo Ferrazza et al. (2015), pode contribuir para o aumento da rentabilidade, devido a redução do custo operacional efetivo.

Em relação aos pontos fracos, um em comum foi a ausência de planejamento e ausência do controle que, para Ferrazza et al. (2015), são imprescindíveis como ferramenta de rotina gerencial e também no planejamento e tomadas de decisão. A propriedade 2 apresentou, também, como ponto fraco, a falta de especialização dos seus funcionários, fato que tem acarretado desperdício de insumos e até mesmo redução da produção diária por falta de conhecimento dos funcionários durante a ordenha e o armazenamento do leite. Ferrazza et al. (2015) salientaram que um baixo nível de investimento em mão de obra afeta diretamente a produtividade.

No que diz respeito aos pontos fundamentais para a criação da missão, grande parte da diferença entre as propriedades desaparece, pois, todos os gestores são unânimes em dizer que a qualidade deve ser o foco da missão. Esta preocupação com a qualidade se deve ao fato de que, segundo Teixeira Júnior et al.
(2015), o preço pago pelos clientes pode ser incrementado se o pecuarista adotar práticas zootécnicas que visam a melhoria da qualidade do leite, proporcionando, assim, um diferencial como forma de bonificação; porém, estas práticas devem ser implementadas sem que haja um aumento nos custos unitários.

Outros dois pontos merecem destaque na Tabela 2. O primeiro é o fato de todos concordarem que a gestão precisa ser aprimorada, e por isso destacam que investimentos em treinamentos fazem parte dos fatores chave para o sucesso do negócio. Em relação ao investimento em capacitação, Paixão et al. (2014) afirmaram que, apesar desse investimento ser pequeno, via SENAR (Serviço Nacional de Aprendizagem Rural), o reflexo destes treinamentos, principalmente do ordenhador, são enormes na qualidade do leite produzido e manejo dos animais. $\mathrm{O}$ segundo ponto destacado foi o investimento em tecnologias que tornem a gestão mais eficaz e ágil, principalmente no que diz respeito à tomada de decisão. De acordo com Lopes (2015), a tecnologia aumenta a produtividade e facilita a vida do pecuarista e trabalhador. Por último, o aumento da qualidade dos produtos vendidos que, conforme apresentado por Teixeira Júnior et al. (2015), tem impacto direto no preço pago pelos laticínios.

A criação da missão e visão são fundamentais para o desenvolvimento estratégico das propriedades, porém, Margit et al. (2015) apontaram que a formulação da visão e da estratégia seria o grande desafio para o administrador da propriedade rural.

Definidos os pontos fundamentais para o alcance do sucesso, os seus desdobramentos se darão dentro das quatro perspectivas do BSC (financeira, do cliente, dos processos internos, do aprendizado e crescimento) (Kaplan e Norton, 1997), por meio dos objetivos em cada uma delas. Os mesmos autores completaram afirmando que dentro das quatro perspectivas, serão incluídos indicadores de medida de desempenho que irão ajudar a empresa a alcançar os resultados. Segundo Padoveze (2009), apesar de o BSC ter toda uma conotação estratégica, sua atuação tem um foco na área operacional, pois a maioria dos indicadores sugeridos é, na verdade, objetivos e metas de cunho operacional, sem se esquecer, do aspecto sistêmico que rege todo seu conceito e que é divido nas quatro perspectivas. 
Na Tabela 3 é possível verificar os indicadores de desempenho propostos para as três propriedades com seus diferentes níveis tecnológicos, bem como os objetivos de cada uma das propriedades dentro das quatro perspectivas do BSC.

Em relação à perspectiva financeira, a busca pela maximização dos resultados é o ponto principal desta perspectiva (Kaplan e Norton, 1997) nas três propriedades. Porém, o aumento do lucro depende da redução do custo e/ou aumento da receita, que por sua vez é influenciada pela quantidade produzida e pelo preço de venda, que, como apresentado por Teixeira Júnior et al. (2015), pode ser alcançado com a melhoria da qualidade do leite produzido.

Tabela 3. Comparativo de indicadores de três propriedades com diferentes escalas de produção e níveis tecnológicos localizadas no sul do estado de Minas Gerais.

\begin{tabular}{|c|c|c|c|}
\hline & Ide 1 - Grande & Propriedade 2 - Média & $\mathrm{na}$ \\
\hline & $\begin{array}{l}\text { Objetivos: } \\
\text { - Aumento da receita e crescimento } \\
\text { de mercado } \\
\text { - Aumento do preço pago } \\
\text { pelo litro do leite } \\
\text { Indicadores: } \\
\text { - Faturamento Mensal Bruto } \\
\text { (FBT); } \\
\text { - Custo Total Mensal (CTM); } \\
\text { - Faturamento Mensal Bruto do } \\
\text { Leite (FBL); } \\
\text { - Custo Mensal do leite (CML); } \\
\text { - Preço de Venda do leite (PVL); } \\
\text { - Participação Mensal da Renda } \\
\text { Bruta do Leite na Renda da } \\
\text { Atividade (PRBL). }\end{array}$ & $\begin{array}{l}\text { Objetivos: } \\
\text { - Redução do Custo Médio; } \\
\text { - Aumento do preço pago pelo litro } \\
\text { do leite } \\
\text { Indicadores: } \\
\text { - Faturamento Mensal Bruto (FBT); } \\
\text { - Custo Total Mensal (CTM); } \\
\text { - Faturamento Mensal Bruto do } \\
\text { Leite (FBL); } \\
\text { - Custo Mensal do leite (CML); } \\
\text { - Preço de Venda do leite (PVL); } \\
\text { - Participação Mensal da Renda } \\
\text { Bruta do Leite na Renda da } \\
\text { Atividade (PRBL). }\end{array}$ & $\begin{array}{l}\text { Objetivos: } \\
\text { - Redução ou Manutenção do } \\
\text { Custo Médio } \\
\text { - Aumento do preço pago pelo } \\
\text { litro do leite } \\
\text { Indicadores: } \\
\text { - Faturamento Mensal Bruto } \\
\text { (FBT); } \\
\text { - Custo Total Mensal (CTM); } \\
\text { - Faturamento Mensal Bruto do } \\
\text { Leite (FBL); } \\
\text { - Custo Mensal do leite (CML); } \\
\text { - Preço de Venda do leite (PVL); }\end{array}$ \\
\hline & $\begin{array}{l}\text { Objetivos: } \\
\text { - Satisfazer o cliente/ comprador; } \\
\text { - Vender produtos com qualidade. } \\
\text { Indicadores: } \\
\text { - Teor de proteína no leite (TPL) } \\
\text { - Teor de gordura no leite (TGL) } \\
\text { - Contagem de células somáticas } \\
\text { (CCS); } \\
\text { - Contagem bacteriana total (CBT); } \\
\text { - Reclamações } \\
\text { clientes/compradores (RC) dos }\end{array}$ & $\begin{array}{l}\text { Objetivos: } \\
\text { - Satisfazer o cliente/ comprador; } \\
\text { - Vender produtos com qualidade. } \\
\text { Indicadores: } \\
\text { - Teor de proteína no leite (TPL) } \\
\text { - Teor de gordura no leite (TGL) } \\
\text { - Contagem de células somáticas } \\
\text { (CCS); } \\
\text { - Contagem bacteriana total (CBT); } \\
\text { - Reclamações } \\
\text { clientes/compradores (RC) dos }\end{array}$ & $\begin{array}{l}\text { Objetivos: } \\
\text { - Satisfazer o cliente/ comprador; } \\
\text { - Vender produtos com qualidade. } \\
\text { Indicadores: } \\
\text { - Teor de proteína no leite (TPL) } \\
\text { - Teor de gordura no leite (TGL) } \\
\text { - Contagem de células somáticas } \\
\text { (CCS); } \\
\text { - Contagem bacteriana total } \\
\text { (CBT); } \\
\text { - Reclamações dos } \\
\text { clientes/compradores (RC) }\end{array}$ \\
\hline 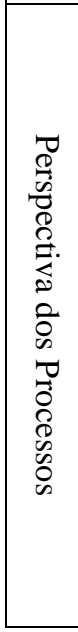 & $\begin{array}{l}\text { Objetivos: } \\
\text { - Desenvolver procedimentos } \\
\text { eficazes à higienização do rebanho e } \\
\text { dos equipamentos utilizados na } \\
\text { ordenha; } \\
\text { - Aperfeiçoar a gestão de estoques; } \\
\text { Indicadores: } \\
\text { - Índice de ocorrências sanitárias; } \\
\text { - Taxa de fecundidade; } \\
\text { - Taxa de mortalidade; } \\
\text { - Custo alimentar por kg de leite } \\
\text { - Produção de leite diária; } \\
\text { - Produção de leite por vaca dia; } \\
\end{array}$ & $\begin{array}{l}\text { Objetivos: } \\
\text { - Desenvolver procedimentos } \\
\text { eficazes à higienização do rebanho } \\
\text { e dos equipamentos utilizados na } \\
\text { ordenha; } \\
\text { Indicadores: } \\
\text {-Índice de ocorrências sanitárias; } \\
\text { - Taxa de fecundidade; } \\
\text { - Taxa de mortalidade; } \\
\text {-Custo alimentar por kg de leite; } \\
\text { - Produção de leite diária; } \\
\text {-Produção de leite por vaca dia; }\end{array}$ & $\begin{array}{l}\text { Objetivos: } \\
\text { - Melhorar o processo de manejo } \\
\text { do gado; } \\
\text { - Desenvolver procedimentos } \\
\text { eficazes à higienização do rebanho } \\
\text { e dos equipamentos utilizados na } \\
\text { ordenha: } \\
\text { Indicadores: } \\
\text { - Produção de leite diária; } \\
\text { - Produção de leite por vaca dia; } \\
\text { - Custo alimentar por kg de leite }\end{array}$ \\
\hline
\end{tabular}


Tabela 3. Comparativo de indicadores de três propriedades com diferentes escalas de produção e níveis tecnológicos localizadas no sul do estado de Minas Gerais.

(continuação)

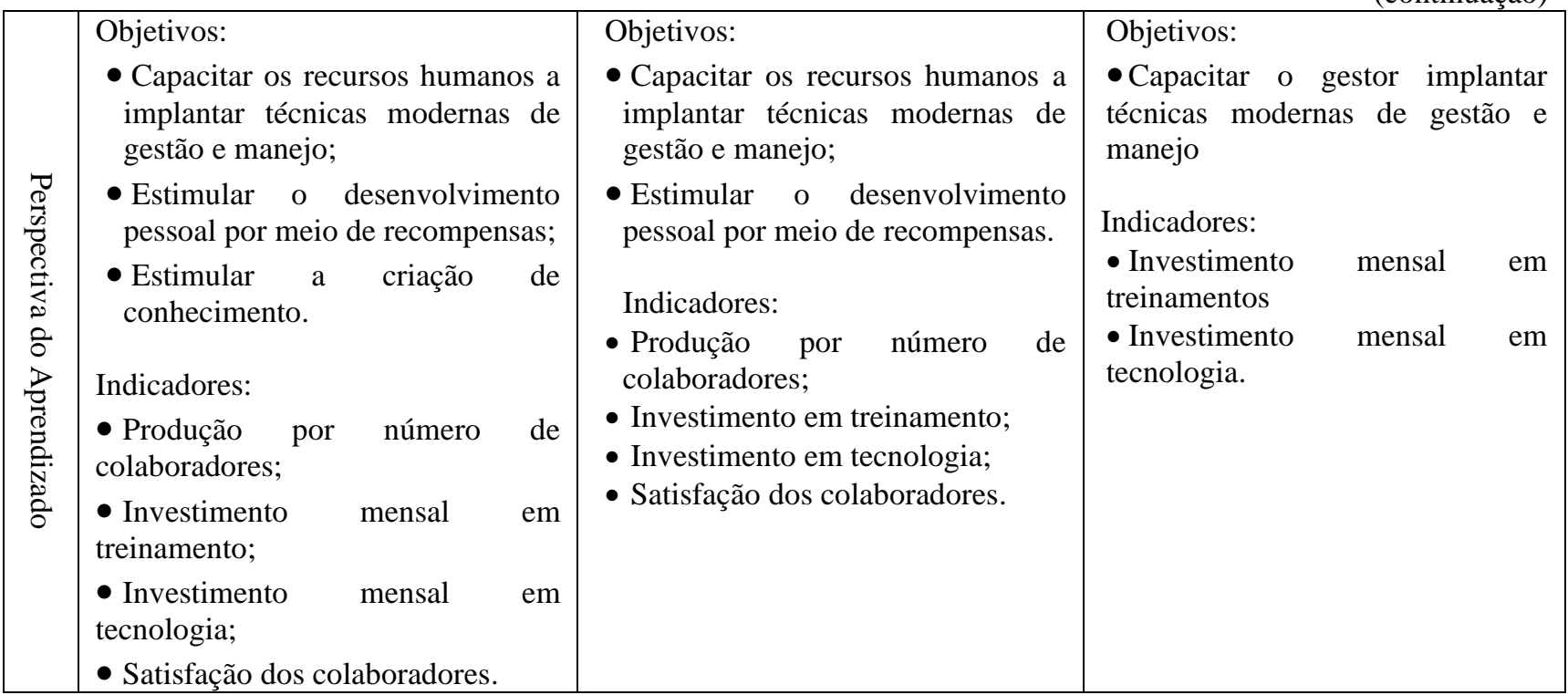

Fonte: Dados da pesquisa

Em relação à perspectiva do cliente, é importante identificar o que irá criar valor para os clientes/compradores, ou seja, é preciso identificar e atender suas necessidades e desejos (Kaplan e Norton, 1997).

No mercado de leite, uma das maiores exigências das agroindústrias é por produtos de melhor qualidade e, para isso, torna-se necessária uma adequação dos produtores de leite a esta nova realidade. A exigência se dá devido ao fato de que o leite cru com pior qualidade, como aquele com contagem de células somáticas elevada, devido ao quadro de mastite, possui maior concentração de plasmina (uma enzima a qual degrada as proteínas do leite); e, devido à estabilidade térmica desta enzima, a vida de prateleira do leite pasteurizado e produtos lácteos ficam comprometidos (Auldist e Hubble, 1998). Além disso, há ainda o efeito negativo no rendimento na fabricação de queijos (Barbano et al., 1991).

No que tange às propriedades 2 e 3 , para eles não há a preocupação pela fidelização do comprador, uma vez que a produção é vendida para aquele que oferecer o melhor preço. Teixeira Júnior et al. (2015) salientaram que o produtor tem dois caminhos para escolher: ou ele busca produzir um leite de qualidade e se beneficia da bonificação e se mantem competitivo, ou ele permanece com sua produção tradicional e fica fadado a ser excluído do sistema. Para Paixão et al. (2014), algumas ações podem fazer com que melhore a qualidade do leite vendido: a melhoria no manejo, higiene na ordenha, sanidade da glândula mamária, manutenção e desinfecção dos equipamentos, entre outras.

A perspectiva dos processos internos apresenta o que deve ser feito dentro da organização para satisfazer às expectativas dos clientes-alvo (Kaplan e Norton, 1997) e, para as propriedades em estudo, o intuito de todas é otimizar a produção por meio de processos mais eficazes. Isto por que, conforme Paixão et al. (2014), processos internos que cuidam para evitar a contaminação do leite devem ser tomados desde a ordenha até o beneficiamento, e são obtidos por meio de boas práticas agropecuárias. Neste sentido, os objetivos estratégicos sobre essa perspectiva são: desenvolver procedimentos eficazes à higienização do rebanho e dos equipamentos utilizados na ordenha.

No que tange à perspectiva do aprendizado e crescimento, os indicadores devem ser orientados constantemente para o crescimento profissional dos recursos humanos (gestor e funcionários) e satisfação dos funcionários nas propriedades 1 e 2 . Conforme Taffarel et al. (2013), os funcionários e ordenhadores bem treinados terão mais cuidado na manutenção das ordenhadeiras, bem como farão sua higienização, evitando a perda de qualidade e até mesmo de toda a produção. Esta perspectiva deve contemplar, também, o investimento em novas tecnologias, inclusive as que se referem à gestão. Com base nisso, capacitar os recursos humanos a implantar técnicas modernas de gestão e manejo, bem como utilizar softwares para controle e 
gestão, além de estimulá-los ao desenvolvimento pessoal, por meio de recompensas, são os objetivos dessas propriedades dentro desta perspectiva.

Tendo como base os indicadores das quatro perspectivas, é possível ainda apresentar o BSC em forma de mapeamento, onde as relações de causa e efeito podem ser claramente vistas. Os mapas estratégicos das propriedades 1,2 e 3 podem ser visualizados nas Figuras 1, 2 e 3, respectivamente.

Figura 1. Mapa estratégico da propriedade 1: grande porte

\section{Crescimento e Sustentabilidade}

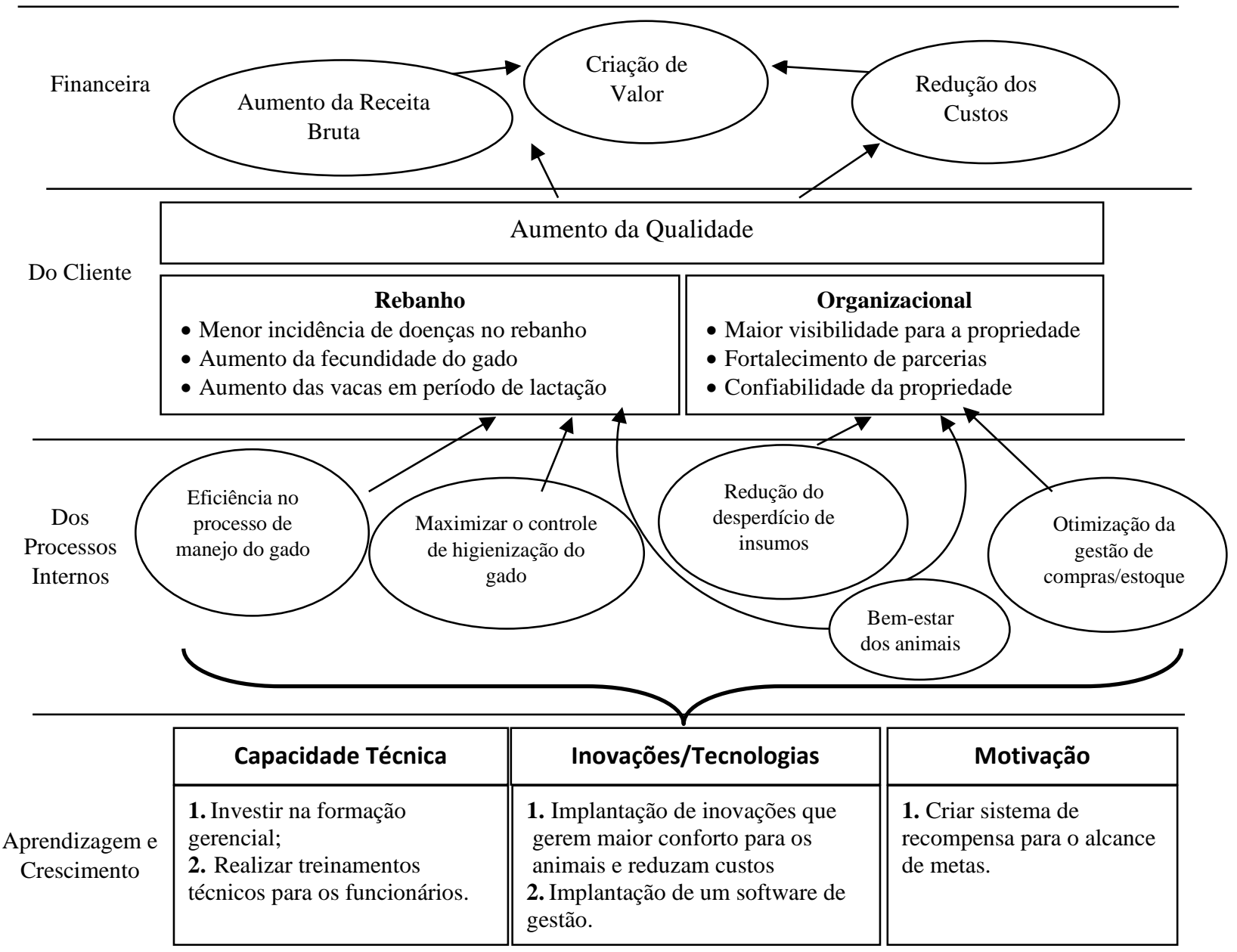

Fonte: Autores

Para a elaboração dos mapas estratégicos, buscou-se desmembrar as diretrizes estratégicas propostas em cada uma das propriedades e vinculá-las às principais áreas operacionais das propriedades, o que facilita a comunicação da estratégia aos interessados na organização. Iniciando a análise pela perspectiva do aprendizado e crescimento, que está pautada basicamente para as três propriedades na implantação de tecnologias que possibilita a redução de custos, como softwares de gestão que auxiliem no gerenciamento da propriedade, além de criar um sistemas de motivação para os funcionários (propriedades 1 e 2) e treinamentos, possibilitará melhoria nos processos internos, seja de ordenha, arraçoamento dos animais, aproveitamento de subprodutos e redução do desperdício, além da adoção de medidas higiênico-sanitárias. A realização destas ações levará os funcionários/proprietário a um maior comprometimento com a operação, além de motivá-los a contribuir com o resultado final da propriedade. Eles terão mais atenção ao desperdício de insumos, realizarão os processos de forma mais eficiente, e a excelência nesses processos irá se traduzir em qualidade final do produto e aumento da produção, o que acarretará 
maior visibilidade e rentabilidade para as propriedades.

Essas ações têm impacto no processo financeiro, pois reduzem o custo médio de produção, além de aumentar o preço pago pelos

Figura 2. Mapa estratégico da propriedade 2: médio porte clientes, pois a qualidade é fator preponderante para a decisão de compra e preço pago pelo litro do leite (Teixeira Júnior et al., 2015). Desta forma, as propriedades conseguirão atingir seu objetivo que é o aumento da rentabilidade.

\section{Crescimento e Inovacão}

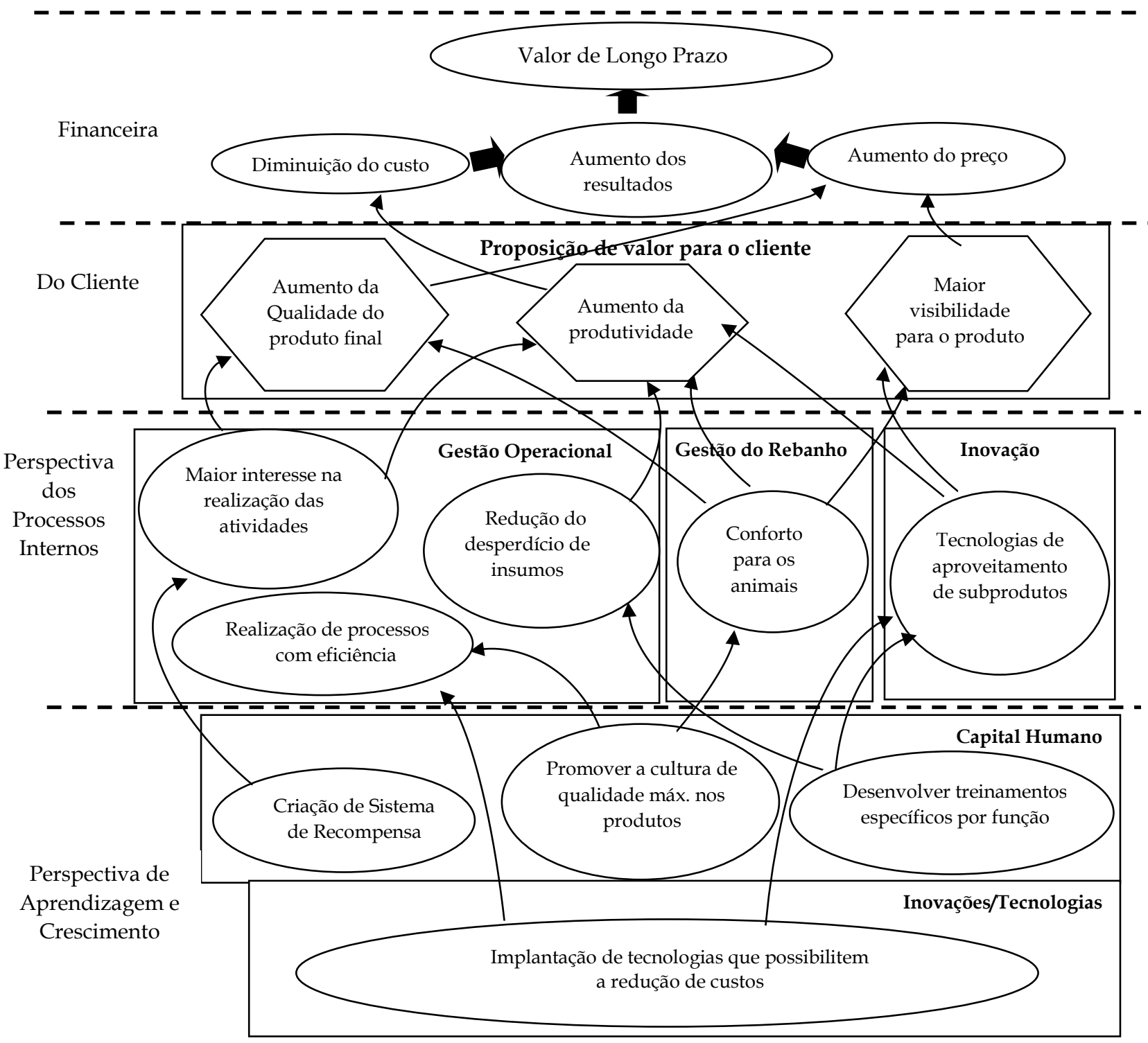

Fonte: Autores

\section{Conclusão}

Verificou-se que o modelo de Balanced Scorecard, proposto por Kaplan e Norton (1997), pode ser aplicado a uma propriedade produtora de leite, independente do seu porte e nível tecnológico; porém, vale destacar que antes de qualquer ação, é preciso que os gestores participem de todo o processo, desde a definição dos objetivos, até a escolha dos indicadores de desempenho, pois é fundamental que eles acreditem na estratégia e desenvolvam a cultura de planejamento estratégico na organização.

Recomenda-se que novos estudos sejam desenvolvidos sobre o modelo Balanced Scorecard nas propriedades produtoras de leite, com o foco em outros aspectos como a aplicação e monitoramento da ferramenta, sendo que o presente estudo buscou trazer a contribuição a respeito da sua aplicabilidade com intuito de melhorar o desempenho da propriedade. 
Compreende-se que o BSC é uma ferramenta gerencial que envolve de maneira profunda o capital humano, que é a base do sucesso de qualquer organização, e acredita-se que quanto maior for o envolvimento desses com a metodologia proposta pelo Balanced Scorecard, maior e melhor serão os resultados.

Figura 3. Mapa estratégico da propriedade 3: pequeno porte

\section{Sustentação/Manutenção - Ganho de Eficiência}

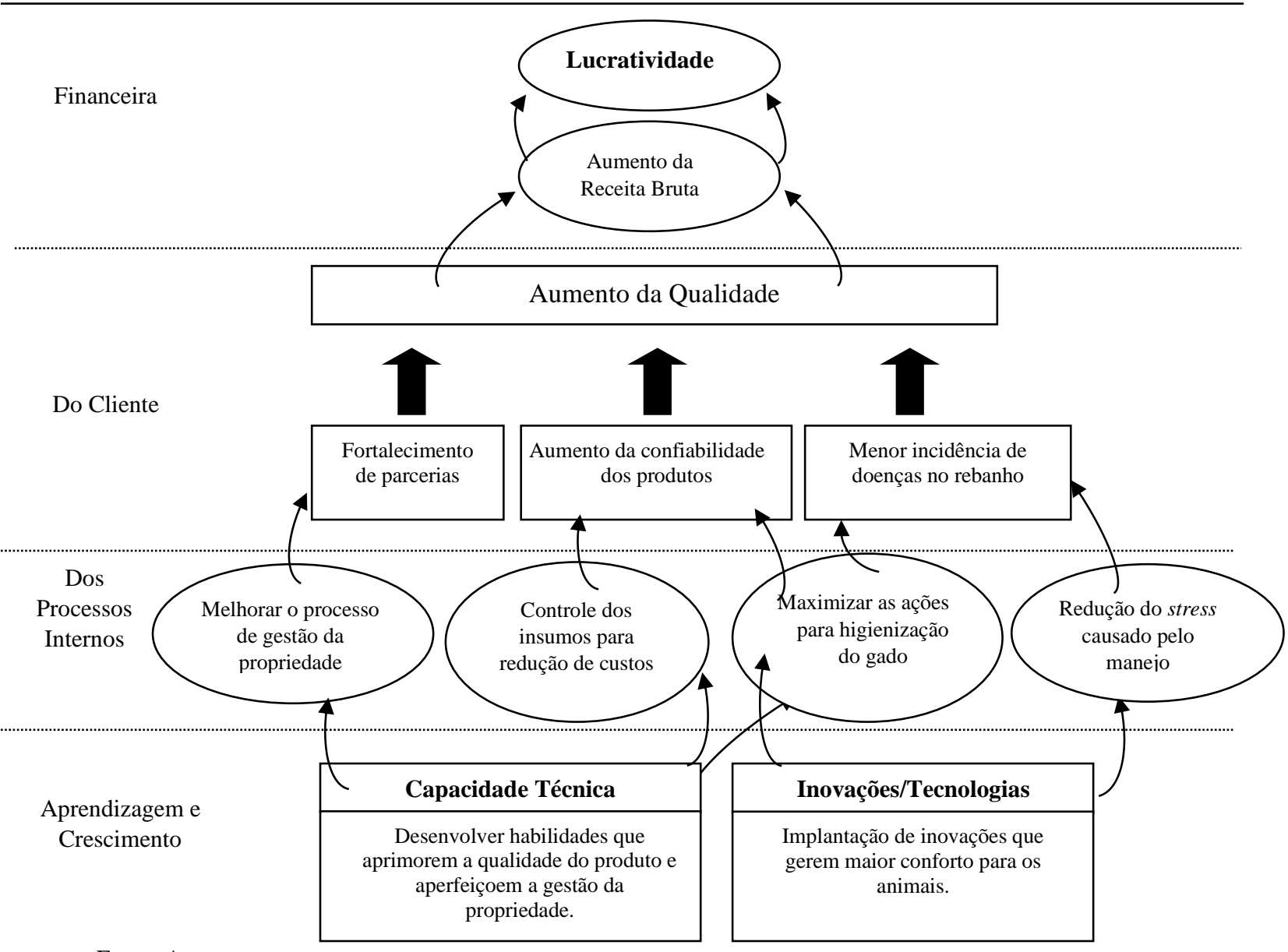

Fonte: Autores

\section{Conflito de Interesse}

Os autores declaram não existir conflito de interesse.

\section{Agradecimentos}

Os autores agradecem à FAPEMIG e ao $\mathrm{CNPq}$, pelo apoio na realização deste estudo.

\section{Referências}

Assaf Neto, A. Finanças corporativas e valor. $7^{\mathrm{a}}$ ed. São Paulo: Atlas, 2014. 824p.

Auldist, M.J.; Hubble, I.B. Effects of mastitis on raw milk and dairy products (Review paper). The Australian Journal of Dairy Technology, 53: 28-36, 1998.
Barbano, D.M.; Rasmussen, R.R.; Lynch, J.M. Influence of milk somatic cell count and milk age on cheese yield. Journal of Dairy Science, 74(2): 369-388, 1991.

Bigliardi, B.; Bottani, E. Performance measurement in the food supply chain - a balanced scorecard approach. Facilities, 28(5/6): 249-260, 2010.

Bryceson, K.P.; Slaughter, G. Alignment of performance metrics in a multi-enterprise agribusiness. Achieving integrated autonomy? International Journal of Productivity and Performance Measurement, 59(4): 325-350, 2010. 
Cousin, M.A.; Bramley, A.J. The microbiology of raw milk. Dairy Microbiology, 1(1): 119-163, 1990.

Ferrazza, R.; Lopes, M.A.; Bruhn, F.R.P.; Moraes, F. Índices de desempenho zootécnico e econômico de sistemas de produção de leite com diferentes tipos de mão de obra. Ciência Animal Brasileira, 16(2): 193-204, 2015.

Gil, A.C. Como elaborar projetos de pesquisa. $4^{\mathrm{a}}$ ed. São Paulo: Atlas, 2002. 175p.

Godinho, R.F.; Soares, V.E.; Bertipaglia, L.M.A.; Dian, P.H.M. Gestão empresarial em sistemas de produção de leite na microrregião de São João Batista do Glória/MG. Ciência et Praxis, 6(12): 39-49, 2013.

Jack, L. The adoption of strategic management accounting tools in agriculture post subsidy reform: a comparative study of practices in the UK, the US, Australia and New Zealand. Chartered Institute of Management Accountants, 5(7): 1-7, 2009.

Kaplan, R.S.; Norton, D.P. A estratégia em ação: Balanced Scorecard. Rio de Janeiro: Elsevier, 1997. 360p.

Lopes, M.A. Gestão na bovinocultura de leite. Lavras: UFLA. Apostila do Curso de especialização "lato sensu" Curso de Extensão Ambiental para o Desenvolvimento Sustentável, 2015.

Margit, P.; Marie, W.; Ludwig, T. The Balanced Scorecard as a management tool for arable farming. International Journal on Food System Dynamics, 6(3): 147-158, 2015.

Oaigen, R.P.; Barcellos, J.O.J.; Christofari, L.F.; Neto, J.B.; Oliveira, T.E.; Prates, E.R. Melhoria organizacional na produção de bezerros de corte a partir dos centros de custos. Revista Brasileira de Zootecnia, 37(3): 580587, 2008.

Padoveze, C.L. Controladoria estratégica e operacional: conceitos, estrutura, aplicação. $2^{\mathrm{a}}$ ed. São Paulo: Cengage Learning, 2009.

Paixão, M.G.; Lopes, M.A.; Pinto, S.M; Abreu, L.R. Impacto econômico da implantação das boas práticas agropecuárias relacionadas à qualidade do leite. Revista Ceres, 61(5): 612621, 2014.

Salomon, D.V. Como fazer monografia. $9^{\mathrm{a}} \mathrm{ed}$. São Paulo: Martins Fontes, 1999.

Shadbolt, N.M. The Balanced Scorecard: A strategic management tool for ranchers. Rangelands, 29(2): 4-9, 2007.

Spector, N. Manual para a redação de teses, dissertações e projetos de pesquisa. Rio de Janeiro: Guanabara Koogan, 2002. 117p.

Taffarel, L.E.; Costa, P.B. Tsutsumi, C.; Todero, E.J.; Pires, C.C.S.C. Manutenção de ordenhadeiras em propriedades familiares do oeste do Paraná. UDESC em Ação, 6(1): 1-12, 2013.

Teixeira Júnior, F.E.P; Lopes, M.A.; Ruas, J.R.M. Effect of payment for milk quality on the profitability of dairy farming. Revista do Instituto de Laticínios Cândido Tostes, 70(1): 24-34, 2015.

Triviños, A.N.S. Introdução à pesquisa em ciências sociais: a pesquisa qualitativa em educação. São Paulo: Atlas, 1987. 175p.

Yin, R.K. Estudo de caso: planejamento e métodos. $3^{\text {a }}$ ed. Porto Alegre: Bookman, 2005. 212p. 